\title{
EU DISPUTE SETTLEMENTS IN THE WTO: SELECTED PENDING CASES
}

\author{
Tamara Perišin, Ana Bobić and Vanda Jakir*
}

\section{Introduction}

The EU is frequently referred to as one of the Titans of the WTO and this is why its trade disputes frequently receive a lot of attention from academics, practitioners and the media. This attention frequently arises at the later stages of the proceedings - during oral hearings, after the $\mathrm{Pa}-$ nel Report or the Appellate Body Report. However, the focus of our study lies primarily on disputes which are still at the very early phase of their development. The scope of this report has required the narrowing down of the subject-matter, and the authors have concentrated on the movement of goods, covering five pending cases.

First, the report covers cases where the EU is the respondent. It looks at the measures which the EU has adopted internally, examining their background and inquiring how these measures affect trade. It is generally known that EU legislation can pose barriers both to internal and to external trade, ${ }^{1}$ and it is interesting that such legislation can be challenged both within the EU - before the European Court, or in the international arena - before WTO bodies. An example of this is the pending disputes on seals ${ }^{2}$ and poultry. ${ }^{3}$

Then, the report looks at measures from third countries which EU traders have considered to be obstacles to trade, and which the EU decided to challenge using the WTO dispute settlement mechanism. These cases in which the EU acts as a complainant concern India's and the Philippines' measures on spirits, ${ }^{4}$ and China's rules on raw materials. ${ }^{5}$

\footnotetext{
Dr Tamara Perišin, MJur (Oxon) is Associate Professor in the Department for European Public Law, Faculty of Law, University of Zagreb. Ana Bobić and Vanda Jakir are graduate students at the Faculty of Law, University of Zagreb.

1 Eg Case C-210/03 Swedish Match AB and Swedish Match UK Ltd $v$ Secretary of State for Health [2004] ECR I-11893.

2 European Communities - Certain Measures Prohibiting the Importation and Marketing of Seal Products, DS369, DS400, DS401.

3 European Communities - Certain Measures Affecting Poultry Meat and Poultry Meat Products from the United States, DS389.

4 India-Certain Taxes and Other Measures on Imported Wines and Spirits, DS380; Philippines - Taxes on Distilled Spirits, DS396

5 China - Measures Related to the Exportation of Various Raw Materials, DS394, DS395, DS398.
} 


\section{European Communities - certain measures prohibiting the importa- tion and marketing of seal products}

\section{Background}

Ever since the seal hunting issue was addressed in the 1980s, when the EC introduced a Directive banning the import of seal pups' fur and related products, ${ }^{6}$ debate has not ceased.

The early beginnings of this intricate problem date from the $19^{\text {th }}$ century, when seal fishery grew as an industry as a result of technical developments. Since then, many measures have been introduced to enhance the productivity of the hunt, as well as to preserve the seal population. For instance, in 1961 the closing date for hunting was set at 5 May, and later this was brought forward to 25 April, which shortened the hunting season. ${ }^{7}$ In 1964, certain species of seals were excluded from hunting, such as hooded seals, or all female seals on birthing patches. ${ }^{8}$ The first quota was set at 245,000 in $1971 .{ }^{9}$ It reached its low, a total of 127,000, in 1976 , and its peak in 2003, when it amounted to $350,000 .{ }^{10}$ Today, the quota is set near to the first one, a total of $275,000 .{ }^{11}$ When it comes to the seal population, some claim that it has increased by $50 \%$ or even $60 \%$ in the last 30 years, ${ }^{12}$ while others maintain quite the reverse is true. ${ }^{13}$

At the moment, the most important piece of legislation regulating this field is Canada's Marine Mammal Regulations, which forms part of the Fisheries Act, adopted in the mid 1960s. ${ }^{14}$ It contains provisions on obligatory hunting licences, various methods of hunting that are intended to reduce to the minimum the amount of distress and pain, a ban on killing seals under 12 months of age, and procedures to be taken if quotas are breached, and so forth. The hunting closing dates are set

6 Council Directive (EEC) 83/129 of 28 March 1983 concerning the importation into Member States of skins of certain seal pups and products derived therefrom [1983] OJ L091 09/04/1983 P 0030 - 0031.

7 The Seal Fishery, 'Regulation \& Quota History'<http://www.thesealfishery.com/seal_ hunt_regulations.php> accessed on 4 November 2010.

8 The Seal Fishery (n 7).

9 The Seal Fishery (n 7).

10 The Seal Fishery (n 7).

11 The Seal Fishery (n 7).

12 The Seal Fishery, 'Sealing History'<http://www.thesealfishery.com/seal_hunt_history2. php> accessed on 4 November 2010.

13 International Fund for Animal Welfare, 'Frequently Asked Questions About the Seal Hunt' <http://www.ifaw.org/ifaw_european_union/join_campaigns/save_baby_seals_ end_the_seal_hunt/seal_hunt_facts_canada_doesn\% $27 t$ twant_you_to_know/shortcut_of_ frequently_asked_questions_\%28faqs\%29_about_the_seal_hunt.php> accessed on 4 November 2010.

14 Department of Justice Canada, 'Marine Mammal Regulations' (SOR/93-56) <http:// laws.justice.gc.ca/en/F-14/SOR-93-56/index.html> accessed on 4 November 2010. 
differently for every region. It can be concluded from the meticulousness of this regulation that Canada has great interest in the seal industry, not only because its exports in seal products reach up to $\$ 18$ million (CAD), of which nearly one third goes to the EU, but also because seal fishery is the only source of income for people in regions where hunting is conducted. ${ }^{15}$

\section{Disputed measure}

Belgium and the Netherlands were the first EU Member States to introduce bans on the importation, transportation, manufacturing, marketing and sale of seal products. This stimulated a Europe-wide discussion and opinion polls on seal hunting which were supposed to lead to a decision on whether to regulate these issues at the EU level. ${ }^{16}$ When in 2007 Canada requested consultations with the European Communities concerning these national measures, one might have assumed that the challenge would make the European legislature reluctant to adopt a piece of Community legislation on the matter. ${ }^{17}$ It is thus very interesting that despite Canada's challenge to national bans on seal products, the European Community still adopted Regulation No 1007/2009 on trade in seal products. ${ }^{18}$ This resulted in another request for consultations by Canada, ${ }^{19}$ and soon afterwards by Norway and Iceland. ${ }^{20}$

\footnotetext{
15 University of British Columbia, Institute for European Studies, "The Issue of Sealing' <http://www.ies.ubc.ca/index.php?option=com_content\&task=view\&id=152\&Item id $=198>$ accessed on 4 November 2010.

16 See the European Food Safety Authority, 'Scientific Opinion on Animal Welfare: Aspects of the Killing and Skinning of Seals' <http://www.efsa.europa.eu/EFSA/efsa_locale-1178620753812_1178671319178.htm> accessed on 8 July 2008; European Commission, 'Commission Assessment of the Animal Welfare Aspects of Seal Hunting' $<$ http://ec.europa.eu/environment/biodiversity/animal_welfare/seals/seal_hunting. htm> accessed on 8 July 2008; European Parliament, 'European Parliamentary Questions' < http://www.europarl.europa.eu/sidesSearch/sipadeMapUrl.do?PROG=QP\&:SORT_ ORDER=DA\&S_REF_QP=\%25\&S_RANK=\%25\&F_MI_TEXT $=$ seal\&MI_TEXT $=$ seal\&LEG_ ID $=68 \mathrm{~L}=\mathrm{EN}>$ accessed on 8 July 2008; H Spongenberg, 'Canada Starts Trade Dispute With the EU over Seals' EUobserver (27 September 2007) <http://euobserver.com/9/24853> accessed on 8 July 2008.

17 Request for consultations by Canada, European Communities - Certain Measures Prohibiting the Importation and Marketing of Seal Products (1 October 2007) WT/DS369/1, G/L/827, G/TBT/D/31.

18 Regulation (EC) No 1007/2009 of 16 September 2009 of the European Parliament and of the Council on trade in seal products [2009] OJ L286/36-39.

19 Request for consultations by Canada, European Communities - Certain Measures Prohibiting the Importation and Marketing of Seal Products (4 November 2009) WT/DS400/1, G/L/909, G/TBT/D/36, G/AG/GEN/87.

20 Request for consultations by Norway, European Communities - Certain Measures Prohibiting the Importation and Marketing of Seal Products (10 November 2009) WT/ DS401/1,G/L/912, G/TBT/D/37, G/AG/GEN/88; Request to join consultations - Communication for Iceland, European Communities - Certain Measures Prohibiting the Importation and Marketing of Seal Products (18 November 2009) WT/DS401/2.
} 
According to its preamble, the Regulation was adopted to protect animal welfare by banning seal products altogether. ${ }^{21}$ On the other hand, the Regulation bears in mind that seal hunting has been a part of the culture and a means of survival for the Inuit, an indigenous people residing in the Arctic and sub-Arctic area. ${ }^{22}$ Hence, the Regulation allows only seal products that result from hunting traditionally conducted by the Inuit. ${ }^{23}$ Nevertheless, the Inuit communities complain since the price, for instance, of seal fur has plummeted almost tenfold since the ban was introduced. ${ }^{24}$

\section{Possible breach of WTO law}

The main position of the complainants is that the European Communities failed to meet their obligations under the WTO; namely Articles I: 1 (Most Favoured Nation Treatment), III:4 (National Treatment) and XI:1 (Import Restrictions) of the General Agreement on Tariffs and Trade (GATT), as well as Articles 2.1 (National Treatment and Most Favoured Nation Treatment) and 2.2 (on technical regulations which should not be unnecessary obstacles to international trade) of the Technical Barriers to Trade Agreement - TBT.

Regarding compliance with the GATT, an important issue in this case is firstly whether the ban in question is applied 'so as to afford protection' to domestic production. While the measure is imposed on all seal products, regardless of their country of origin, it should be noted that from the EU's point of view, the majority of seal products are in fact foreign, coming from Newfoundland, Eastern Quebec and Nunavut, where seal hunting forms an essential part of the economy. ${ }^{25}$ Consequently, some argue ${ }^{26}$ that the measure at hand is probably protectionist, especially when one takes into consideration that the EU has focused solely on seals (and the related industry), while at the same time it encourages, for example, the highly industrialised and inhumane breeding of livestock. ${ }^{27}$

\footnotetext{
21 Regulation (EC) No 1007/2009 (n 18) recital 9.

22 Regulation (EC) No 1007/2009 (n 18) recital 14.

23 Regulation (EC) No 1007/2009 (n 18) art 3 (1).

24 Lee Carter, 'Canadian Seal Hunt Collapsing' BBC News (18 June 2009) <http://news. bbc.co.uk/2/hi/8106539.stm> accessed on 23 November 2010.

25 International Economic Law and Policy Blog, "From Dolphins to Turtles to Seals: The Next Trade and the Environment Dispute' <http://worldtradelaw.typepad.com/ ielpblog/2007/07/from-dolphins-t.html> accessed on 23 November 2010.

26 Simon Lester, 'The WTO Seal Products Dispute: A Preview of the Key Legal Issues' 14 (2) The American Society for International Law (13 January 2010) <http://www.asil.org/files / insight100113pdf.pdf> accessed on 4 November 2010.

27 Although the EU, its Member States and regional constituencies are adopting measures with a view to improving the treatment of animals. For example, Catalonia recently banned bull-fighting (amendment to the Animal Protection Act No 5687 of 6 August.2010, 61833-4 (Llei 28/2010, del 3 d'agost, de modiicació de l'article 6 del text refós de la Llei de protecció dels animals, aprovat pel Decret legislatiu 2/2008).
} 
Moreover, certain 'hypocritical' arguments are often raised against the EU, such as the fact that in France, for instance, there is no guarantee that sheep are not conscious while they are slaughtered, ${ }^{28}$ or the fact that every four to five days more animals are killed for fur in Europe than seals in Canada in one year. ${ }^{29}$

Another question raised when it comes to discrimination is whether the products in question can be considered as 'like', since Article III:4 GATT prohibits different treatment of such products. According to Regulation No $1007 / 2009,{ }^{30}$ seal products are differentiated on the basis of the process and production methods (PPMs). In other words, the ban on trade does not apply to seal products derived from traditional Inuit hunts, where the use of a hakapik ${ }^{31}$ in a special manner assures the painless treatment of seals. ${ }^{32}$ Although in some cases, such as Tuna/ Dolphin, it is stated that the PPMs are irrelevant for determining the likeness' of products, ${ }^{33}$ more recent tests of likeness, such as those based on the regulatory purpose, suggest that PPMs can be taken into account. ${ }^{34}$ But even if the case was decided on the basis on Article XI GATT and not Article III GATT, the measure might still be justified. In Shrimp/Turtle, dealing with the US import ban on shrimps caught with techniques resulting in the incidental killing of sea turtles, both the Panel and the Appellate Body in the case determined that justifications from Article XX GATT can be invoked (although the US measure was not justified as it was contrary to the chapeau of Article XX constituting unjustifiable discrimination between countries where the same conditions prevail). ${ }^{35}$

Secondly, it is questionable whether the measure at hand is necessary in the context of Article 2.2 TBT which provides that

28 In Canada, the aforementioned Marine Mammal Regulations provide this guarantee.

29 'Seal Hunting - Political Animals' The Economist (14 May 2009) < http:/ / www.economist. com/node/13649231> accessed on 4 November 2010.

30 Regulation (EC) No $1007 / 2009$ (n 18).

31 A hakapik is a club, of Norwegian design, used for killing seals. The hakapik is a multipurpose hunting tool-a heavy wooden club, with a hammer head (used to crush a seal's skull), and a hook (used to drag away the carcass).

32 This includes use that results in the seal's instant death. Canada's Marine Mammal Regulations prescribe the same method.

33 Panel Report, United States - Restrictions on Imports of Tuna (3 September 1991) DS21/R, DS21/R, unadopted, BISD 39S/155, hereinafter referred to Tuna/Dolphin, para 5.15.

34 Appellate Body Report, European Communities - Measures Affecting Asbestos and Asbestos-Containing Products (12 March 2001) WT/DS135/AB/R, paras 101 and 102; Appellate Body Report, Chile - Taxes on Alcoholic Beverages (13 December 1999) WT/DS87/AB/R, WT/DS1 10/AB/R.

35 Panel Report, United States - Import Prohibitions on Certain Shrimp and Shrimp Products (15 May 1998) WT/DS58/R, paras 7.62, 7.63; and Appellate Body Report (12 October 1998) WT/DS58/AB/R, para 186; hereinafter referred to as Shrimp/Turtle. 
'[m]embers shall ensure that technical regulations are not prepared, adopted or applied with a view to or with the effect of creating unnecessary obstacles to international trade... [and that f]or this purpose, technical regulations shall not be more trade-restrictive than necessary to fulfil a legitimate objective, taking account of the risks non-fulfilment would create'. ${ }^{36}$

Surprisingly enough, the Regulation itself addresses this question. According to its preamble, the reason behind the ban lies in the impossibility to establish an effective mechanism to control the treatment of seals in the production process. ${ }^{37}$ On the other hand, the complainants claim the exact opposite - that simple labelling would achieve the goal, an option that is completely overruled by the Regulation. ${ }^{38}$ Since both parties firmly defend their standpoints, it seems that this issue will be vigorously argued and supported by evidence from both sides.

Finally, the EU could invoke the protection of public morals, animal life and health, or even the conservation of exhaustible natural resour$\operatorname{ces}^{39}$ as a defence. While the basic connection between the ban and the set goals is more or less clear, what still remains vague is how the exemption for Inuit hunters ${ }^{40}$ contributes to the protection of animal life or the conservation of exhaustible natural resources. Furthermore, the fact that the breach of TBT is an issue in this case might result in an analysis of its relation to Article XX of the GATT. In fact, it seems that it would be possible for the EU to use not only the justifications set out in Article XX, but any other ones (not only because Article III:4 GATT can be interpreted in a way that products which can be differentiated on the basis of any legitimate regulatory purpose are not 'like', ${ }^{41}$ but also because the list of justifications in Article 2.2 of the TBT is inexhaustible). However, in the latter case, the justification of the Regulation should be supported by scientific evidence as well.

\footnotetext{
36 Agreement on Technical Barriers to Trade (12 April 1979) art 2.2.

37 Regulation (EC) No 1007/2009 (n 18) recital 11.

38 Regulation (EC) No 1007/2009 (n 18) recital 12.

39 Article XX (a), (b) and (g) GATT.

40 Regulation (EC) No 1007/2009 (n 18).

${ }^{41}$ Panel Report, United States - Measures Affecting Alcoholic and Malt Beverages (19 June 1992) DS23/R, adopted, BISD 39S/206 paras 5.23-5.26; Panel Report, United States - Taxes on Automobiles (11 October 1994) DS31/R, unadopted para 5.10; Appellate Body Report, Chile - Alcohol (n 34), paras 62, 71; Appellate Body Report, EC-Asbestos (n 34). See also DH Regan, "Regulatory Purpose and "Like Products" in Article III:4 of the GATT (with Additional Remarks on Article III:2)' (2002) 36 (3) Journal of World Trade 443; DH Regan, 'Further Thoughts on the Role of Regulatory Purpose under Article III of the General Agreement on Tariffs and Trade' (2003) 37 (4) Journal of World Trade 737; T Perišin, Free Movement of Goods and Limits of Regulatory Autonomy in the EU and WTO (TMC Asser Press, The Hague 2008) 141-159.
} 


\section{Other parallel procedures}

It seems that the complaining party is attempting to devalue the necessity of the Regulation twofold. Firstly, the hunting communities are proposing the adoption of the Universal Declaration on the Ethical Harvest of Seals ${ }^{42}$ ('We Care'). According to their public announcement, their aim is to establish a common international position on ethical standards for the seal harvest, to adopt national codes of ethics and certification of hunting practices and even to have a United Nations Universal Declaration on the Ethical Seal Harvest ratified. ${ }^{43}$

Secondly, the Canadian Inuit ${ }^{44}$ lodged a lawsuit before the European General Court for the annulment of the EC Regulation in question. ${ }^{45}$ At first, the Court temporarily suspended the ban in order to properly consider the legal challenge. ${ }^{46}$ However, this interim injunction applied only to seal hunters who are parties in this case, which induced a wave of dissatisfaction among other Canadian hunters. Most recently, the Court reached a completely different decision. When it assessed the interim measure, it concluded that the applicants' arguments on severe financial damage and the risk of suicide among youths in Inuit communities cannot be accepted. In other words, the Court, after all, introduced a total ban until it decides on the legality of the prohibition altogether. ${ }^{47}$ Perhaps this period before the Court's final decision will show whether the ban truly endangers the Inuit communities, therefore anticipating the final outcome of this dispute.

The main position of the Inuit communities is that the European Parliament and Council erred in law when using Article 114 TFEU (Approximation of laws in the field of the internal market) as the basis for adopting the Regulation in question, that the principles of subsidiarity and proportionality were infringed and, finally, that they were denied their rights under Article 8 (Right to respect private and family life), read in the light of Article 9 (Freedom of thought, conscience and religion) and

\footnotetext{
42 Universal Declaration on the Ethical Harvest of Seals: A Canadian Proposal. An Initiative of the Honourable Céline Hervieux-Payette, PC, Senator of Canada (22 April 2009) <http:// www.sealsonline.org/_files/ENG_UD\%20FINAL\%20April\%202009.pdf> accessed on 4 November 2010.

43 Universal Declaration on the Ethical Harvest of Seals <http://www.sealsonline.org/seal-universal-declaration.php> accessed 4 November 2010.

44 A group of Inuit organisations and other seal hunters' communities.

45 Case T-18/10 Inuit Tapiriit Kanatami ea $v$ Parliament and Council [2010] OJ C100/41.

46 'Canadian seal hunters claim win over EU ban' EUBusiness (20 August 2010) <http:// www.eubusiness.com/news-eu/canada-hunting.5vn> accessed on 4 November 2010.

47 Case T-18/10 R II Ordonnance du Président du Tribunal du 25 octobre $2010<\mathrm{http}: / /$ curia.europa.eu/jurisp/cgi-bin/gettext.pl?lang=fr\&num=79898974T1910\%20RII0018_2\& doc $=T \&$ ouvert $=T \&$ seance $=O R D>$ accessed on 4 November 2010.
} 
Article 10 (Freedom of expression) of ECHR, Article 1 of Protocol 1 to the ECHR (Right to property), as well as their right to be heard. ${ }^{48}$

All of the above sheds new light on this dispute - it seems that a balance among three different grounds - EU law, WTO law and international law - is necessary in order to find a solution. In addition, taking into account the estimated duration of the dispute of three years and the cost of $\$ 10$ million, Canada will certainly have to put in a great deal of effort to save a $\$ 7$ million industry. ${ }^{49}$

\section{European Communities - certain measures affecting poultry meat and poultry meat products from the United States}

\section{Background}

The dispute dates back to 1997, when the EU first banned the use of pathogen reduction treatments (PRTs) on poultry. ${ }^{50}$ It prohibited the trade of poultry that was treated with any substance other than water unless such a substance had been approved by the EU. This was a problem for US manufacturers as many other treatments of poultry were approved by the US federal government and routinely used in US chicken and turkey plants. Consequently, in 2002, the United States asked the EU to approve the use of four PRTs on poultry destined for export there: chlorine dioxide, acidified sodium chlorate, trisodium phosphate, and peroxyacids. ${ }^{51}$ However, the EU rejected the approval of these substances for poultry treatment. ${ }^{52}$ It had also not published or otherwise made available the process of approving a substance.

It is worth mentioning that the EU measures caused a significant decrease in poultry trade between the two countries. Prior to 1997, when the prohibition took effect, US exports of broiler and turkey meat to the 15 countries that then constituted the EU were reported to total nearly 32,000 MT with a value of $\$ 44.4$ million. ${ }^{53}$ Now that the EU consists of

\footnotetext{
48 Case T-18/10 Inuit Tapiriit Kanatami (n 45).

49 Simon Lester, 'WTO Litigation Costs and the Seal Products Case' International Economic Law and Policy Blog (28 July 2009) <http: / / worldtradelaw.typepad.com/ielpblog/2009/07/ wto-litigation-costs.html> accessed on 4 November 2010.

50 R Johnson and GS Becker 'US-EU Poultry Dispute' Congressional Research Service (8 January 2010) <www.crs.gov R40199> accessed on 4 November 2010, 1.

51 Johnson and Becker (n 56) 3.

52 Council Decision of 18 December 2008 rejecting the proposal from the Commission for a Council Regulation implementing Regulation (EC) No 853/2004 of the European Parliament and of the Council as regards the use of antimicrobial substances to remove surface contamination from poultry carcasses 2009/121/EC.
}

53 Johnson and Becker (n 50) 2. 
27 countries, one estimate values the lost market for the US at between $\$ 200$ million and \$300 million annually. ${ }^{54}$

On 16 January 2009, the United States requested consultations with the European Communities regarding the above-mentioned measures..$^{55}$ On 8 October 2009, the United States requested the establishment of a Panel, which was established on 19 November 2009.56

\section{The disputed measure}

The main disputed measure which prohibits the treatment of poultry with any substance other than water (unless approved by the EU) is Regulation (EC) 853/2004, ${ }^{57}$ namely Article 3(2). The Article reads, as follows:

Food business operators shall not use any substance other than potable water - or, when Regulation (EC) No 852/2004 or this Regulation permits its use, clean water - to remove surface contamination from products of animal origin, unless use of the substance has been approved in accordance with the procedure referred to in Article 12(2). ${ }^{58}$

One should immediately notice that this measure does not differentiate between domestic (from EU countries) and imported (from third countries) poultry, since its addressees are all food business operators, without reference to their origin. Although applied in the same manner to both domestic and imported products, these measures can still have negative impacts on trade. The measure at hand defines poultry by the process and production methods. Poultry treated in a different manner (with substances other than water) is not even considered poultry from the EU law point of view. ${ }^{59}$ On the other hand, as US food business operators mainly produce poultry using PRTs, it is impossible for them to export to the EU, since, according to the mentioned EU definition of poultrymeat, they do not export poultrymeat. This causes a heavier burden on US food business operators, as they must take supplementary measures to comply with

\footnotetext{
54 Johnson and Becker (n 50) 2.

55 European Communities - Certain Measures Affecting Poultry Meat and Poultry Meat Products from the United States - Request for Consultations by the United States (20 January 2009) WT/DS389/1 shttp://www.wto.org/english/tratop_e/dispu_e/cases_e/ds389_e. htm> accessed on 4 November 2010.

56 European Communities - Poultry (n 55).

57 Regulation (EC) No 853/2004 of the European Parliament and of the Council of 29 April 2004 laying down specific hygiene rules for food of animal origin [2004] L135.

58 Regulation 853/2004 (n 57) art 3.

59 Council Regulation (EEC) No 1906/90 of 26 June 1990 on certain marketing standards for poultry [1990] OJ L173 art 2 reads as follows: 'For the purposes of this Regulation:
}

1. "poultrymeat" means: poultrymeat suitable for human consumption, which has not undergone any treatment other than cold treatment to ensure its preservation'. 
the EU rules. One might argue that the measure was introduced 'so as to afford protection to domestic production' and that it is thus contrary to Article III GATT (national treatment). However, the US does not argue this, perhaps since already in the Tuna/Dolphin cases ${ }^{60}$ PPMs were characterised as not falling within this GATT provision.

The US is also disputing the following measures: Article 6 of the same Regulation 853/2004, ${ }^{61}$ as well as Council Regulation (EC) No $1234 / 2007$ establishing a common organisation of agricultural markets and on specific provisions for certain agricultural products, ${ }^{62}$ including Annex XIV (B)(II)(2); the rejection of the EC Standing Committee on Food Chain and Animal Health (SCoFAH) of the Commission's proposal regarding the removal of surface contamination from poultry carcasses of 2 June 2008; the EU Agricultural and Fisheries Council's rejection of the Commission's proposal regarding the removal of surface contamination from poultry carcasses of 18 December 2008; and any amendments, related measures, or implementing measures.

\section{Possible breach of WTO law}

The complainant contends that the above-mentioned documents show inconsistency with the following WTO obligations:

- Article 2.2 SPS (which permits only those measures necessary to protect human, animal, and plant life or health and that are based on scientific evidence); Article 5 SPS (which governs risk assessment and determination of the appropriate level of SPS protection, with the objecti-

60 Panel Report, Tuna/Dolphin (n 33); Panel Report, United States - Restrictions on Imports of Tuna (16 June 1994) DS29/R, unadopted, hereinafter referred to as Tuna/Dolphin II.

61 Products of animal origin from outside the Community:

1. Food business operators importing products of animal origin from third countries shall ensure

that importation takes place only if:

(a) the third country of dispatch appears on a list, drawn up in accordance with Article 11 of Regulation (EC) No [*]/2004, of third countries from which imports of that product are permitted; [text omitted]

(ii) in the case of fresh meat, minced meat, meat preparations, meat products and MSM, the product was manufactured from meat obtained in slaughterhouses and cutting plants appearing on lists drawn up and updated in accordance with Article 12 of Regulation (EC) No [*]/2004 or in approved Community establishments ...[text omitted];

(c) the product satisfies:

(i) the requirements of this Regulation, including the requirements of Article 5 on health and identification marking;

(ii) the requirements of Regulation (EC) No [*]/2004; and

(iii) any import conditions laid down in accordance with Community legislation governing import controls for products of animal origin, and... [text omitted].

62 Council Regulation (EC) No 1234/2007 of 22 October 2007 establishing a common organisation of agricultural markets and on specific provisions for certain agricultural products (Single CMO Regulation). 
ve of minimising trade impact); Article 8 SPS (on control, inspection, and approval procedures aimed at treating imports no less favourably than domestic products); and Annex C (1) (on control, inspection and approval procedures for products to comply with sanitary and phytosanitary measures);

- Article X:1 GATT (which sets forth the obligation to publish trade regulations); Article XI:1 GATT (which enshrines the general elimination of quantitative restrictions);

- Article 4.2 of the Agricultural Agreement (which brings about a prohibition of resort to border measures other than customs duties);

- Article 2 TBT (which is also intended to ensure that TBT measures do not discriminate against imports or create unjustified barriers to trade).

It is worth specially addressing the US claim that the measure is contrary to Articles 2.2 and 5 SPS, as both articles prevent even nonprotectionist measures (which are in some other way irrational). In $\mathrm{Ja}$ pan - Agricultural Products ${ }^{63}$ and Japan - Apples, ${ }^{64}$ the Appellate Body interpreted Article 2.2 providing for the obligation of states not to maintain SPS measures without sufficient scientific evidence as requiring ' $a$ rational or objective relationship between the SPS measure and the scientific evidence' which 'is to be determined on a case-by-case basis and will depend upon the particular circumstances of the case, including the characteristics of the measure at issue and the quality and quantity of the scientific evidence'. ${ }^{65}$ Concerning Article 5 SPS in EC-Hormones, the Appellate Body interpreted Article 5 (particularly 5.1) as requiring that measures based on a higher level of protection than the relevant international standard would have done had to be based on a risk assessment. ${ }^{66}$

The US in this case argues that this measure lacks scientific evidence. To uphold its assertions, the US made use of scientific opinion published by EFSA (European Food Safety Authority) on 2 April 2008, which found that 'there are currently no published data to conclude in whatever way' that these substances, when applied to poultry carcasses,

${ }_{63}$ Panel Report, Japan - Measures Affecting Agricultural Products $(27$ October 1998) WT/ DS76/R; Appellate Body Report, Japan - Measures Affecting Agricultural Products (22 February 1999) WT/DS76/AB/R..

64 Panel Report, Japan - Measures Affecting the Importation of Apples (15 July 2003) WT/ DS245/R;, Appellate Body Report, Japan - Measures Affecting the Importation of Apples (26 November 2003) WT/DS245/AB/R,.

65 Appellate Body Report, Japan - Apples (n 64) para 84, emphasis added. For further analysis of these cases, see Perišin (n 41).

66 Appellate Body Report, European Communities - Measures Concerning Meat and Meat Products (Hormones) (16 January 1998) WT/DS26/AB/R, WT/DS48/AB/R, para 193. 
cause 'acquired reduced susceptibility' (a build-up in resistance to the PRTs), or cause resistance to therapeutic antimicrobials. ${ }^{67}$

However, it seems that the EU will call upon the precautionary principle. Indeed, already, in its Resolution, ${ }^{68}$ the European Parliament has called upon the precautionary principle, as well as Regulation (EC) $178 / 2002 .{ }^{69}$

\section{China - measures related to the exportation of various raw materials}

\section{Background of the case}

For several years China has been imposing certain restrictions on the export of certain raw materials. China is one of the largest extractors and exporters of the raw materials in question which can rarely be found elsewhere. These raw materials are essential to many globally traded products, from cell phones to toothpaste. The most frequent argument used against China is that it is trying to benefit its own manufacturers. This can be seen from the effect of these measures - the prices on its internal market remain artificially low, while the rest of the world struggles with high prices, or even stagnation and job loss. ${ }^{70}$

Although this issue has been raised in numerous attempts at negotiation, China has not changed its practice. As a result, the European Communities requested consultations with China under the WTO, regarding 32 measures through which China is restraining exports. ${ }^{71}$ At the same time, the United States also lodged a request, and Mexico soon followed. ${ }^{72}$ The dispute has drawn the attention of other WTO members, consequently amounting to a long list of third parties - Argentina, Brazil,

\footnotetext{
67 'Scientific Option of the Panel on Biological Hazards on a Request from DG SANCO on the assessment of the possible effect of the four antimicrobial treatment substances on the emergence of antimicrobial resistance' (2008) 659 EFSA Journal 1-26.

68 European Parliament resolution of 19 June 2008 on imports of poultry carcasses [2009] C $286 \mathrm{E} / 07$.

${ }^{69}$ Regulation (EC) No 178/2002 of the European Parliament and of the Council of 28 January 2002 laying down the general principles and requirements of food law, establishing the European Food Safety Authority and laying down procedures in matters of food safety, art 7.

70 'EU requests WTO consultations on Chinese export restrictions on raw materials' Europa Press Releases RAPID (23June 2009) <http://europa.eu/rapid/pressReleasesAction. do? reference $=\mathrm{MEMO} / 09 / 287 \&$ format $=\mathrm{HTML} \&$ aged $=0 \&$ language $=\mathrm{EN} \&$ guiLanguage $=\mathrm{en}>$ accessed on 4 November 2010.

71 China - Measures Related to the Exportation of Various Raw Materials: Request for Consultations by the European Communities (25 June 2009) WT/DS395/1, G/L/889.

72 China - Measures Related to the Exportation of Various Raw Materials: Request for Consultations by the United States (25 June 2009) WT/DS394/1, G/L/888; China - Measures Related to the Exportation of Various Raw Materials: Request to Join Consultations - Communication from Mexico (9 July 2009) WT/DS394/5, WT/DS395/5.
} 
Canada, Chile, Colombia, Ecuador, India, Japan, the Republic of Korea, Mexico, Norway, Chinese Taipei, Turkey and Saudi Arabia. ${ }^{73}$ Finally, a Panel has been composed. ${ }^{74}$

\section{Disputed measure}

China has applied export restrictions, in the form of export quotas and export duties, on certain raw materials such as bauxite, coke, fluorspar, silicon carbide, zinc, yellow phosphorus and others. ${ }^{75}$ In addition, China has imposed additional requirements related to the export of the said materials. Such measures, which number at least 32 in total, include: restricting the right to export on the basis of prior export experience; establishing criteria that foreign-invested enterprises must satisfy in order to export that are different from those that domestic entities must satisfy; requiring exporters to pay fees; maintaining a minimum export price system and requiring the examination and approval of export contracts and export prices. ${ }^{76}$

\section{Possible breach of WTO law}

The complainants argue that the Chinese measures breach the GATT provisions which prohibit overburdening fees and formalities connected with imports and exports (Article VIII GATT) as well as non-pecuniary restrictions on trade (Article XI GATT), and which impose an obligation regarding the publication and administration of trade regulations (Article X GATT), and that the measures breach the Protocol on the Accession of the People's Republic of China ${ }^{77}$ ('Accession Protocol': paragraphs 1.2,78

\footnotetext{
73 List available at <http://www.wto.org/english/tratop_e/dispu_e/cases_e/ds394_e. htm> <http://www.wto.org/english/tratop_e/dispu_e/cases_e/ds395_e.htm> <http:// www.wto.org/english/tratop_e/dispu_e/cases_e/ds398_e.htm> all accessed on 4 November 2010 .

74 China - Measures Related to the Exportation of Various Raw Materials: Constitution of the Panel Established at the Requests of the United States, the European Communities and Mexico (30 March 2010) WT/DS394/8, WT/DS395/8, WT/DS398/7.

75 All contested Chinese legislation is available in China - Measures Related to the Exportation of Various Raw Materials: The First Written Submission of the United States of America (1 June 2010) <http://www.worldtradelaw.net/wtodisputesubmissions/us/DS394_USFirstWrittenSubmission.pdf $>$ accessed on 4 November 2010.

76 China - Raw Materials (n 75).

77 Protocol on the Accession of the People's Republic of China (23 November 2001) WT/L/432

78 Paragraph 1.2: 'The WTO Agreement to which China accedes shall be the WTO Agreement as rectified, amended or otherwise modified by such legal instruments as may have entered into force before the date of accession. This Protocol, which shall include the commitments referred to in paragraph 342 of the Working Party Report, shall be an integral part of the WTO Agreement.'
} 
$5.1,^{79} 5.2,{ }^{80} 8.2^{81}$ and $11.3^{82}$ of Part 1) and the Working Party Report ${ }^{83}$ (paragraph $342^{84}$ ). Furthermore, the complaining parties argue that the measures imposed also nullify or impair the benefits accrued under these agreements.

In response, China argues that its export duties are necessary to protect human, animal or plant life or health, or, in other words, that they are justified under Article XX(b) of the GATT. ${ }^{85}$ China's aim is to decrease primary production (production from raw materials in crude ores) because such production is less environmentally friendly than secondary production. ${ }^{86}$ Increased secondary production, which is a consequence of reducing primary production, will lead to a reduction in health risks associated with primary production. ${ }^{87}$ Against this, the complainants submit that China has failed to establish that the measures in question actually achieve the set aim. ${ }^{88}$ Furthermore, the complainants suggest

79 Paragraph 5.1: 'Without prejudice to China's right to regulate trade in a manner consistent with the WTO Agreement, China shall progressively liberalize the availability and scope of the right to trade, so that, within three years after accession, all enterprises in China shall have the right to trade in all goods throughout the customs territory of China, except for those goods listed in Annex 2A which continue to be subject to state trading in accordance with this Protocol. Such right to trade shall be the right to import and export goods. All such goods shall be accorded national treatment under Article III of the GATT 1994, especially paragraph 4 thereof, in respect of their internal sale, offering for sale, purchase, transportation, distribution or use, including their direct access to end-users. For those goods listed in Annex 2B, China shall phase out limitation on the grant of trading rights pursuant to the schedule in that Annex. China shall complete all necessary legislative procedures to implement these provisions during the transition period.'

80 Paragraph 5.2: 'Except as otherwise provided for in this Protocol, all foreign individuals and enterprises, including those not invested or registered in China, shall be accorded treatment no less favourable than that accorded to enterprises in China with respect to the right to trade.'

81 Paragraph 8.2: 'Except as otherwise provided for in this Protocol, foreign individuals and enterprises and foreign-funded enterprises shall be accorded treatment no less favourable than that accorded to other individuals and enterprises in respect of the distribution of import and export licences and quotas.'

82 Paragraph 11.3: 'China shall eliminate all taxes and charges applied to exports unless specifically provided for in Annex 6 of this Protocol or applied in conformity with the provisions of Article VIII of the GATT 1994.'

${ }^{83}$ Report of the Working Party on the Accession of China (10 November 2001) WT/ $\operatorname{MiN}(01) / 3$.

84 Containing a conclusion that certain commitments from the Report shall be incorporated in para 1.2 of the Draft Protocol.

85 China - Measures Related to the Exportation of Various Raw Materials, 'Opening oral statement of the complainants at the first substantive meeting of the panel with the parties' (31 August 2010) <http:/ /www.worldtradelaw.net/wtodisputesubmissions/us/DS394395-398_ComplainantsOralStatement.pdf> accessed on 4 November 2010, para 102.

86 China-Raw Materials (n 85).

87 China-Raw Materials (n 85).

88 China-Raw Materials (n 85). 
that the set aim might have been achieved by other means, for instance by various restrictions on the extraction of raw materials. ${ }^{89}$

Regardless of the plausibility of these lines of argument, it is still questionable whether Article XX can be applied at all. To be more exact, China seems to be in breach of not only the GATT but its Accession Protocol as well. In order to fully assess the issue, it should first be determined what role the Accession Protocol has in the present case, as well as in WTO law. Unlike any other accession protocol, China's Accession Protocol is not standardised. ${ }^{90}$ In other words, it is quite unique since it offers a different set of trade rules which elaborate, expand, modify or deviate from the existing WTO agreements. ${ }^{91}$ According to paragraph 1.2 of the Accession Protocol, when it comes to China's trade, the Protocol forms an integral part of the WTO agreement. ${ }^{92}$ The latter was confirmed by the Panel in China - Automobile Parts. ${ }^{93}$ On the one hand, the provisions that impose stronger obligations on China than other WTO Agreements - the so-called 'WTO-Plus' obligations ${ }^{94}$ - are particularly relevant for this case because they are the provisions that China seems to be in breach of. In fact, paragraphs 5.1, 5.2 and 8.3 of the Accession Protocol correspond to Article III of the GATT (National Treatment), but while Article III deals with goods, the aforementioned paragraphs ${ }^{95}$ address the national treatment of foreign persons and their trading opportunities. Hence, the Accession Protocol is in certain ways broader than the GATT in terms of national treatment, to the extent that its scope encompasses not only goods but also the persons who are trading in those goods. ${ }^{96}$ Although at first glance such a conclusion does not predict an outcome to the dispute, it should be noted that in China - Publications and Audiovisual Products ${ }^{97}$ both the Panel and the Appellate Body concluded that China had not violated the GATT, but that it violated its Accession Protocol. On the other hand, the Accession Protocol is to some extent narrower. ${ }^{98}$ Its paragraph 11.3

\footnotetext{
89 China-Raw Materials (n 85) para 112.

90 Julia Ya Qin, “WTO-Plus” Obligations and their Implications for the World Trade Organization Legal System: An Appraisal of the China Accession Protocol' (2003) 37 (3) Journal of World Trade 483-522, 2003.

91 Ya Qin (n 90).

92 As cited (n 79).

93 Panel Report, China - Measures Affecting Imports of Automobile Parts, Report of the Panel (18 July 2008) WT/DS339/R, WT/DS340/R, WT/DS342/R, para 7.295.

94 Ya Qin (n 90).

95 Full provisions cited above in notes $79,80,82$.

96 Ya Qin (n 90).

97 Panel Report, China - Measures Affecting Trading Rights and Distribution Services for Certain Publications and Audiovisual Entertainment Products (12 August 2009) WT/ DS363/R, para 8.4; Appellate Body Report (21 December 2009) WT/DS363/AB/R, para 417.

98 Ya Qin (n 90).
} 
requires that China eliminates all export taxes and charges, ${ }^{99}$ except those for the 84 products listed in Annex 6. These products may be subject to export duties up to a maximum rate as specified in the Annex. In the present case, the majority of the raw materials are not listed, while for others the export duty rates are set higher than agreed. The question raised in this issue is whether China can use Article XX of the GATT to justify the measures that are in breach of the Accession Protocol, or, more generally, whether Article XX can be invoked to provide exemption from the obligations of the accession instruments or other agreements.

The earlier case law has not given a clear-cut answer. For instance, in China - Audiovisual Products, the Appellate Body found that 'China may rely upon the introductory clause of paragraph 5.1 of its Accession Protocol and seek to justify the contested provisions as necessary to protect public morals in China, within the meaning of Article XX(a) of the GATT'. ${ }^{100}$ In the Report in US - Shrimp (Thailand) and US - Customs Bond Directive ${ }^{101}$ the Appellate Body first concluded that for the sake of argument it should be assumed that there was a possibility to apply Article $\mathrm{XX}$ of the GATT as a justification for breaching other agreements (in the cases at hand, the Anti-Dumping Agreement was in question). ${ }^{102}$ But, after finding that the measures in question did not meet the conditions of Article XX, the Appellate Body decided it was superfluous to determine whether Article XX could have been invoked in the first place. ${ }^{103}$

Taking into consideration both of the paths that the Panel and the Appellate Body may take in the present case, it is difficult to see whether the outcome of this dispute will significantly contribute to WTO law in relation to the applicability of Article XX outside the GATT.

\section{India - certain taxes and other measures on imported wines and spi- rits and the Philippines - taxes on distilled spirits}

\section{Background}

India, being one of the largest markets in the world, is an attractive destination for exports, and the same is true for the export of spirits from the EU. The Indian market for spirits is one of the largest in the world,

\footnotetext{
99 Report of the Working Party on the Accession of China (n. 83).

100 Appellate Body Report, as cited above, n 97, para 233.

${ }^{101}$ Report of the Appellate Body, United States - Measures Relating To Shrimp From Thailand, United States - Customs Bond Directive For Merchandise Subject To Antidumping/ Countervailing Duties (16 July 2008) WT/DS343/AB/R.

102 Report of the Appellate Body, US - Shrimp/Turtle (n 101) para 310.

${ }^{103}$ Report of the Appellate Body, US - Shrimp/Turtle (n 101) para 319.
} 
amounting in 2007 to about 130 million nine-litre cases. ${ }^{104}$ The corresponding figure for wine is 1.5 million nine-litre cases. ${ }^{105}$

However, trade in spirits has been affected by measures adopted by several Indian states, including Maharashtra, Goa, Tamil Nadu, Karnataka and Andhra Prandesh. After the introduction of their measures, EU exports to India dropped dramatically. In 2007, EU exports of spirits to India amounted to about $€ 57$ million (out of a total $€ 7$ billion exported to more than 150 countries). ${ }^{106}$ However, in $2008^{107}$ these figures dropped to $€ 52$ million. ${ }^{108}$ Concerning trade in wine in particular, in $2007 \mathrm{EU}$ exports to India amounted to about $€ 11$ million (out of a total $€ 6$ billion for its global exports), ${ }^{109}$ and in 2008 exports decreased to $€ 8$ million). ${ }^{110}$

As part of its 2007 Market Access Strategy, the European Commission has focused new resources on removing unfair barriers to trade in key growing markets such as India. ${ }^{11}$ The EU claims that such barriers hamper access to the Indian market of EU bottled wines and spirits. On 22 September 2008, the EU requested consultations with India regarding the above-mentioned measures. ${ }^{112}$ Afterwards, the EU requested supplementary consultations on 15 December 2008, and again on 4 May 2009 and 16 November 2009. ${ }^{113}$

The EU is involved in another factually similar dispute with the Philippines. The EU argues that the tax system of the Philippines has prevented EU exporters from fully participating in the Philippine market

\footnotetext{
104 'EU to request new WTO consultations on Indian wine and spirits taxes', EUROPA Press Releases Rapid

<http: / / europa.eu/rapid/pressReleasesAction.do?reference=IP/08/1382\&type=HTML> accessed 2 September 2010.

105 'EU to request new WTO consultations' (n 104).

106 'EU writes to WTO over high state taxes on foreign liquor' The Economic Times (25 November 2009) Economy $\leq$ http://economictimes.indiatimes.com/news/economy/foreigntrade/EU-writes-to-WTO-over-high-state-taxes-on-foreign-liquor/articleshow/5265660. cms $>$ accessed on 2 September 2010.

${ }^{107}$ In 2008 the laws were amended by the Indian states of Maharashtra, Goa, Karnataka and Tamil Nadu. The dates of the amendments were taken from relevant documents submitted by the EU to WTO. All the relevant documents are available at <http://docsonline.wto.org/imrd/gen_searchResult.asp?RN=0\&searchtype=browse\&q1=\%28\%40meta $\% 5 \mathrm{~F}$ Symbol+WT\%FCDS380\%FC\%2A\%29\&language=1> accessed on 3 November 2010 .

108 As cited above (n 107).

109 Ya Qin (n 90)..

110 As cited above (n 107).

111 Ya Qin (n 90).

112 India - Certain Taxes and Other Measures on Imported Wines and Spirits. The document and current status of the dispute can be found at <http://www.wto.org/english/tratop_e/ dispu_e/cases_e/ds380_e.htm> accessed on 4 November 2010.

113 India - Certain Taxes and Other Measures (n 112).
} 
of alcoholic beverages, which has seen steady growth in recent years. ${ }^{114}$ While sales of local spirits have grown by over $8 \%$ since 2005 , overall sales of imported spirits have actually declined during the same period. ${ }^{115}$ From 2004 to 2007, EU exports of spirits to the Philippines fell from around $€ 37$ million to $€ 18$ million. ${ }^{116}$ EU Trade Commissioner Catherine Ashton pointed out that '[t]his long-running problem has prevented EU exporters from competing fairly in the Philippine market, and has led to a sharp decrease in imports of European spirits'. ${ }^{117}$

On 29 July 2009, the EU requested consultations with the Philippines ${ }^{118}$ and on 10 December the EU requested the establishment of a panel. ${ }^{119}$

\section{The disputed measures}

The disputed Indian measures consist in particular of the following:

- the Indian states of Andhra Prandesh, Maharashtra and Karnataka subject imported bottled wines to taxation in excess of domestic like products. Maharashtra also applies a prohibited subsidy by exempting from 'excise duty' its local wines made from local grapes;

- in the Indian State of Tamil Nadu, imported spirits are burdened with a 'special fee on the import of excisable articles'. ${ }^{120}$ Imported spirits are excessively taxed, hence the measure constituting de jure discrimination. ${ }^{121}$

Furthermore, the EU is also challenging a non-fiscal measure introduced by the Tamil Nadu State which restricts the wholesale and retail distribution of imported bottled wines and spirits. The contested measu-

\footnotetext{
114 'EU requests WTO consultations with the Philippines over unfair taxation of spirits' EUROPA Press Releases Rapid

<http://europa.eu/rapid/pressReleasesAction.do?reference=IP/09/1200\&format=HTML\& aged $=0 \&$ language $=$ en\&guiLanguage $=e n>$ accessed on 2 October 2010 .

115 'EU requests WTO consultations with the Philippines' (n 114).

116 'EU requests WTO consultations with the Philippines' (n 114).

117 'EU requests WTO consultations with the Philippines' (n 114).

118 Philippines - Taxes on distilled spirits. The document and current status of the dispute can be found at <http://www.wto.org/english/tratop_e/dispu_e/cases_e/ds396_e.htm> accessed on 2 October 2010.

119 Philippines - Taxes on distilled spirits (n 118).

${ }^{120}$ Section 18-BB of the Tamil Nadu Prohibition Act (1937) as amended by the Tamil Nadu Prohibition (Amendment) Act, 2008.

${ }^{121}$ The measure reads as follows:

'A special fee at such rate not exceeding rupees 450 per proof litre, as the State Government may, from time to time, by notification specify, shall be levied on all excisable articles permitted to be imported under this Act' Act No 23 of 2008 to amend the Tamil Nadu Prohibition Act (1937) art 18-BB.
} 
re was introduced in the Tamil Nadu Liquor (Licence and Permit) Rules, 1981, as amended in 2008. ${ }^{122}$ The import of liquor in Tamil Nadu is prohibited. ${ }^{123}$ With Rule XI-B, ${ }^{124}$ the Tamil Nadu State Market Corporation was granted the exclusive privilege of supplying by wholesale and selling by retail imported wines and spirits from outside India. Later, Tamil Nadu amended the challenged discriminatory restrictions on the wholesale and retail distribution of imported bottled wines and spirits. ${ }^{125}$ Despite this, indications that de facto discrimination may still occur put this Indian state under close monitoring. ${ }^{126}$

- Karnataka State applies the 'additional special fee', which subjects imported wines to internal taxes in excess of domestic like products.

The disputed Philippine measure concerns Section 141 of the National Internal Revenue Code of 1997 which establishes an excise tax regime which the EU argues adversely affects imports of distilled spirits. ${ }^{127}$ In essence, under this regime, distilled spirits produced from the sap of nipa, coconut, cassava, camote or buri palm, or from the juice, syrup or sugar of the cane, provided that such materials are produced commercially in the country where they are processed into distilled spirits, are

\footnotetext{
${ }^{122}$ Amendments to the Tamil Nadu Liquor (licence and permit) Rules 1981 (GOMs No 40, Prohibition and Excise (VIII) 1 July 2008) No SRO A-19 (a-1)/2008 and SRO A-19(a-2)/2008.

${ }^{123}$ Chapter II, General provisions, Rule 3 of the Tamil Nadu Liquor (licence and permit) Rules 1981, as amended.

${ }^{124}$ As cited above (n 123).

${ }^{125}$ India - Certain Taxes and Other Measures on Imported Wines and Spirits: Request for Consultations by the European Communities (25 September 2008) WT/DS380/1, G/L/855, G/SCM/D79/1. All the relevant documents are available at: <http://docsonline.wto.org/ imrd/gen_searchResult.asp?RN=0\&searchtype=browse\&q1=\%28\%40meta\%5FSymbol+WT $\%$ FCDS380\%FC\%2A\%29\&language $=1>$ accessed on 3 November 2010 .

126 India-Certain Taxes and Other Measures on Imported Wines and Spirits (n 125).

127 The National Internal Revenue Code of 1997 as amended and consolidated up to 1 March 2009.
}

The Philippines' Section 141 of the National Internal Revenue Code of 1997, as amended and implemented, provides in part as follows: 'Distilled Spirits - On distilled spirits, there shall be collected (...) excise taxes as follows:

(a) If produced from the sap of nipa, coconut, cassava, camote, or buri palm or from the juice, syrup or sugar of the cane, provided such materials are produced commercially in the country where they are processed into distilled spirits, per proof liter, Eleven pesos and sixty-five centavos (P11.65).

(b) If produced from raw materials other than those enumerated in the preceding paragraph, the tax shall be in accordance with the net retail price per bottle of seven hundred and fifty milliliter $(750 \mathrm{ml}$.) volume capacity (excluding the excise tax and the value-added tax) as follows:

(1) Less than Two hundred and fifty pesos (P250) - One hundred twenty-six pesos (P126), per proof liter;

(2) Two hundred and fifty pesos (P250) up to Six hundred and Seventy-five pesos (P675) Two hundred and fifty-two pesos (P252), per proof liter; and

(3) More than Six hundred and seventy-five pesos (P675) - Five hundred and four pesos (P504), per proof liter.'... 
subject to a flat tax rate (11.65 pesos in 2009). ${ }^{128}$ These raw materials are indigenous to the Philippines. At the same time, imported spirits produced from other raw materials are subject to a system of price bands at substantially higher tax rates (between 126 and 504 pesos in 2009). ${ }^{129}$

\section{Possible breach of WTO law}

Both cases deal with an alleged breach of Article III GATT, containing the national treatment principle. Article III: 1 articulates a general principle that internal measures should not be applied 'so as to afford protection to domestic production'. This general principle informs the rest of Article III. ${ }^{130}$ We will first analyse the possible breach of Article III:2, and then of Article III:4.

In both India - Alcohol and Philippines - Alcohol, the EU argues that there is a breach of Article III:2, ie that fiscal measures breach the national treatment principle. In factually similar cases, Japan - Alcohol ${ }^{131}$ and Chile - Alcohol ${ }^{132}$ (where the Appellate Body clarified Japan - Alcohol in paragraphs 62 and 71 of the report), the Appellate Body looked at the measures' protectionist purpose - not the purpose in the sense of the subjective intention of the legislators, but at the 'the purpose or objectives of a Member's legislature and government as a whole', since these are pertinent 'to the extent that they are given objective expression in the statute itself'. ${ }^{133}$ Consequently, 'a measure's purposes, objectively manifested in the design, architecture and structure of the measure, are intensely pertinent to the task of evaluating whether or not that measure is applied so as to afford protection to domestic production'. ${ }^{134}$

Further, in its report in Japan - Alcohol, the Appellate Body held that

examining whether a national measure was consistent with Article III:2, first sentence, meant examining only two elements - one being 'likeness' and the second being the fact whether national taxes were applied to imported products 'in excess of' those applied to domestic ones. ${ }^{135}$

So, it is necessary to examine these two elements. Concerning the first element 'likeness' - regardless of many theoretically possible approaches to analysing this (ranging from an approach based on the

\footnotetext{
${ }^{128}$ National Internal Revenue Code (n 127).

${ }^{129}$ National Internal Revenue Code (n 127).

130 Appellate Body Report, Japan-Alcohol (4 October 1996) WT/DS/8,10-11/AB/R, 4.

${ }^{131}$ Appellate Body Report, Japan -Alcohol (n 130).

${ }^{132}$ Appellate Body Report, Chile - Alcohol (n 34).

${ }^{133}$ Appellate Body Report, Chile - Alcohol (n 34) para 62.

${ }^{134}$ Appellate Body Report, Chile - Alcohol (n 34) emphasis omitted.

${ }^{135}$ Appellate Body Report, Japan-Alcohol (n130)18-20.
} 
objective characteristics of the product to one based solely on the legitimate regulatory purpose), it seems that the Philippines and India will have a hard time proving that the products concerned are not like (especially when they differentiate between distilled spirits on the basis of the raw materials used as in the earlier cases of US - Malt Beverages, ${ }^{136}$ and Japan - Alcohol). The Philippines could, however, claim that these products are not like as they are differentiated on the basis of physical characteristics. The second element, that the national taxes are applied to imported products 'in excess of' those applied to domestic ones, can easily be seen in the measure itself, where the tax rates of the products vary from 11.65 pesos to 125 and even 265 pesos per proof litre. If this dispute settlement process reaches the Panel phase, the Panel would without much doubt apply the previous conclusions.

In India - Alcohol, the EU also claims that there is a breach of Article III:4, presumably by Tamil Nadu State which restricts the wholesale and retail distribution of imported bottled wines and spirits. For a measure to be in breach of Article III:4, it has to treat 'like products' less favourably, so as to afford protection to domestic production. Regarding 'likeness', one needs to bear in mind that this concept is not the same as the one mentioned in Article III:2, first sentence. The term should be interpreted more broadly than the term in Article III:2, first sentence, but more narrowly than the concept of Article III:2 as a whole, encompassing 'like products' and 'directly competitive or substitutable'. ${ }^{137}$ But since Tamil Nadu's measure expressly differentiates between these products solely on the criterion of origin, it can be stated without doubt that they are to be treated as 'like' products. Concerning treatment 'less favourable so as to afford protection to domestic production', one needs to analyse the protectionist purpose of the disputed measure. As the Appellate Body stated in Korea-Beef, ${ }^{138}$ in order for a measure to be deemed to treat imported products less favourably, it should be assessed whether the measure in question modifies the conditions of competition in the relevant market to the detriment of imported products. As mentioned above, the Tamil Nadu State Market Corporation was granted the exclusive privilege of supplying by wholesale and selling by retail imported wines and spirits from outside India. Such a situation distorts competition conditions in the following way: foreign producers cannot access the Tamil Nadu market unless the Tamil Nadu State Market Corporation decides to purchase foreign liquor from them. The EU contends that the wholesale and retail

\footnotetext{
${ }^{136}$ Panel Report US -Malt Beverages (n 41). Compare with Case 168/78 C. v France [1980] ECR 00347.

${ }_{137}$ Appellate Body Report, EC - Asbestos (n 34) para 99.

${ }^{138}$ Appellate Body Report, Korea - Measures Affecting Imports of Fresh, Chilled and Frozen Beef (11 December 2000) WT/DS161/AB/R, WT/DS169/AB/R, paras 134-137.
} 
of imported wines and spirits for general sale have de facto been denied in Tamil Nadu. ${ }^{139}$ On the other hand, domestic liquor producers can access their market by simply obtaining a licence, as regulated by the Tamil Nadu Liquor (licence and permit) Rules. ${ }^{140}$ If one was to apply the reasoning given in Korea-Beef, ${ }^{141}$ the disputed Tamil Nadu measure would be found in breach of Article III:4.

India, regarding this particular measure, might attempt to justify it by asserting that the products were not 'like'. Article III:4 GATT can be interpreted in a way that products which can be differentiated on the basis of any legitimate regulatory purpose are not 'like'. ${ }^{142}$ India's claims would be very weak, as the disputed measure is origin-specific. ${ }^{143}$ It remains doubtful that behind this origin-specific measure there is an origin-neutral purpose. Nevertheless, it is possible that India seeks recourse to Article XX derogations. ${ }^{144}$ The protection of morals, or human life or health, could have been invoked as a justification. Nevertheless, for a measure to be saved by Article XX derogation, it should not be 'applied in a manner which would constitute a means of arbitrary or unjustifiable discrimination between countries where the same conditions prevail, or a disguised restriction on international trade'. ${ }^{145}$ Hence, the prohibition of the wholesale and retail of alcohol should have been applied to both domestic and imported spirits. Therefore, it seems that India would remain unsuccessful, as the contested measures expressly differentiate between domestic and imported spirits, thus constituting unjustifiable discrimination.

\section{Concluding remarks}

For everyone specialising in EU law and policy, it is interesting to see how far the EU is present and active in the international arena.

\footnotetext{
${ }_{139}$ The claims were taken from relevant documents submitted by the EU to WTO on 18 November 2009. All the relevant documents are available at: <http://docsonline.wto.org/ imrd/gen_searchResult.asp?RN=0\&searchtype=browse\&q1=\%28\%40meta\%5FSymbol+WT \%FCDS380\%FC\%2A\%29\&language $=1>$ accessed on 3 November 2010.

140 Tamil Nadu Liquor (licence and permit) Rules 1981 (GOMs No 40, Prohibition and Excise (VIII) 1 July 2008), No SRO A-19 (a-1)/2008 and SRO A-19(a-2)/2008.

${ }^{141}$ See n 139.

${ }^{142}$ As cited above (n 41).

${ }^{143}$ As Don Regan points out, 'origin-specificity raises a strong presumption of illegality both because it is rare that an origin-neutral purpose requires an origin-specific measure and because an origin-specific measure is particularly likely to be resented by the burdened foreign interests'. D Regan, 'Regulatory Purpose and "Like Products"' (n 41) 457 footnote 41. 144 ' $[\mathrm{t}]$ he fact that an interpretation of Article III:4, under those rules, implies a less frequent recourse to Article XX (b) does not deprive the exception in Article XX (b) of effet utile.' Appellate Body Report, EC-Asbestos (n 34) para 115.

${ }^{145}$ Chapeau of Art XX GATT.
} 
Those specialising in the internal dimension of EU law (eg in internal market law) can find it useful to see in practical examples how EU legislation and its decision-making process can have external trade effects. In general, studies show that the single market has facilitated both the EU's internal and external trade ${ }^{146}$ (and one can assume that this has mostly been due to mutual recognition and to partial harmonisation which have made it easier for products to be marketed throughout the EU). However, the EU's positive integration can also create obstacles to trade - either because of the complex nature of the EU's decision-making process or because of the adopted outcome of legislation. On the one hand, the process of decision-making itself may be responsible for creating trade barriers as, for example, was the case in the $E C-$ Biotech $^{147}$ dispute which largely arose due to the fact that EU Member States have different attitudes towards GMOs. ${ }^{148}$ On the other hand, it is not only the legislative process that can cause obstacles to trade, but the legislative outcome as well. Harmonisation can bring about rules which are more trade restrictive than rules which had previously existed in most Member

146 C Allen, M Gasiorek and A Smith, 'Trade Creation and Trade Diversion' (1996) The Single Market Review Series, Subseries IV - Impact on Trade and Investment. Europa <http:// ec.europa.eu/internal_market/economic-reports/docs/studies/stud12_en.pdf> accessed on 7 December 2010..

147 Panel Reports, European Communities - Measures Affecting the Approval And Marketing of Biotech Products (29 September 2006) WT/DS291/R, WT/DS292/R, WT/DS293/R.

148 Their disagreement led to several types of trade barriers to the movement of goods which existed at both national and EC level, and which were all challenged within the WTO. Firstly, since the relevant EC directives and regulations that were in force allowed Member States to prohibit or restrict trade in biotech products which had already been approved for Community-wide marketing in accordance with relevant Community law, many obstacles were created by individual Member States. Secondly, the EC itself stopped approving biotech products pending the adoption of the EU's new regulatory regime, so during this period there was a de facto moratorium on approvals. It is interesting that even after the Panel's decision in EC-Biotech, which found the EC to be in breach of its WTO obligations, most EU Member States still do not intend to change their policies, despite the Commission's proposals supported by certain other Member States. For example, the Council recently rejected the Commission's proposals requesting Austria to lift its ban on two types of genetically modified maize. The UK, the Netherlands, the Czech Republic and Sweden voted against the rejection. See, $2773^{\text {rd }}$ Council Meeting, Environment, Press Release, (18 December 2006) Europa Press Releases Rapid 16164/06 (Presse 349), provisional version, available at <http://www.eu2006.fi/news_and_documents/conclusions/vko51/en_ GB/1166511048482/_files/76448471833378833/default/92249.pdf> accessed on 8 July 2008; and 'Austria Finds Backing for GMO Bans' (19 December 2006) EurActiv <http:// www.euractiv.com/en/environment/austria-finds-backing-gmo-bans/article-160555> accessed on 8 July 2008. Furthermore, it is interesting to note that the Council is frequently so split on the issue of biotech products that it cannot reach a qualified majority either for approving or for rejecting a product. $2849^{\text {th }}$ Council Meeting Agriculture and Fisheries, Press Release (provisional version) (18 February 2008) Council of the European Union 6199/08 (Presse 33) <http://www.consilium.europa.eu/ueDocs/cms_Data/docs/pressData/en/agricult/98819.pdf> accessed on 8 July 2008, 6. This shows how the EC's 'federal' nature and its dynamics of decision-making create obstacles to trade. 
States (regulatory peaks ${ }^{149}$ ). This is the situation in the current disputes on seals and poultry.

For others interested in the EU's external relations or in international trade, it can be equally interesting to see which markets EU traders are trying to penetrate and what kind of obstacles other WTO members have raised. The cases concerning India's and the Philippines' measures on spirits and China's rules on raw materials are among these, and it will be intriguing to follow their development. 